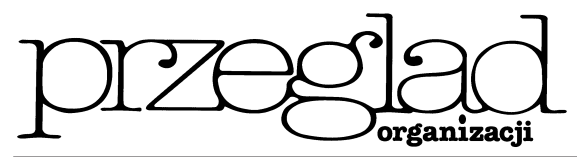

\title{
Potrzeby adresatów marketingu kadrowego i ich specyfika
}

https://doi.org/10.33141/po.2005.78.15

Przegląd Organizacji, Nr 7/8 (786/787), 2005, ss. 58-60

www.przegladorganizacji.pl

\section{Agnieszka Izabela Baruk}

Towarzystwo Naukowe Organizacji i Kierownictwa (TNOiK)

\section{Potrzeby zawodowe i ich determinanty}

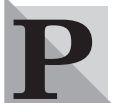

otrzeby pracowników można rozpatrywać w dwóch wymiarach: zawodowym i osobistym.

Potrzeby zawodowe związane są z przynależnością do określonej organizacji i realizowaniem w niej konkretnych zadań. Według autorki można je zdefiniować jako potrzeby powstające w świadomości człowieka z chwilą jego zatrudnienia, które ulegają różnym przemianom w różnych okresach jego aktywności zawodowej, wynikającym z etapu cyklu życia pracownika, w jakim się on aktualnie znajduje.

Ogół potrzeb o charakterze zawodowym można z kolei podzielić na trzy grupy:

- potrzeby odzwierciedlające dążenia pracownika, które wynikają ze specyfiki wykonywanej przez niego pracy; - potrzeby wynikające z przynależności pracownika do określonego zespołu pracowniczego, co wiąże się z odgrywaniem przez niego roli podwładnego, przełożonego lub obu tych ról jednocześnie;

- potrzeby zwiąane ze zdobyciem pracy w wybranej przez daną osobę firmie (występujące w przypadku potencjalnych pracowników należących do otoczenia konkretnej organizacji).

Oczywiście wszystkie potrzeby zawodowe w zależności od tego, do której kategorii adresatów działań z zakresu marketingu personalnego należy pracownik, dzielą się też na dwa następujące zbiory:

- potrzeby wspólne, odczuwane przez wszystkich członków danej organizacji, przy czym sa one odczuwane z różnym natężeniem, co wynika m.in. z zajmowanego przez pracownika miejsca w hierarchii organizacyjnej;

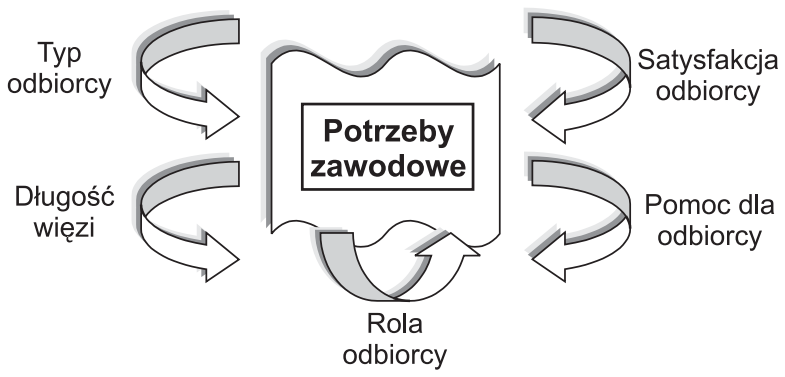

Rys. 1. Determinanty potrzeb adresatów marketingu personalnego

Źródło: opracowanie własne na podstawie L. EDVINSSON, M.S. MALONE, Kapitat intelektualny. Poznaj prawdziwa wartość swego przedsiębiorstwa, odnajdujac jego ukryte korzenie, Wydawnictwo Naukowe PWN, Warszawa 2001, s. $73-75$.
- potrzeby odrębne, odczuwane przez poszczególne jednostki lub wąskie grupy pracownicze determinowane indywidualnym systemem wartości, ambicjami zawodowymi itp.

Należy podkreślić, że wszystkie potrzeby zawodowe pozostają również w bezpośrednim związku z potrzebami osobistymi, a ich zaspokojenie warunkuje realizację oczekiwań osobistych, przy czym zależność ta jest dwukierunkowa.

Do najważniejszych czynników decydujących o odczuwaniu odmiennych potrzeb (zwłaszcza zawodowych) przez poszczególnych adresatów marketingu personalnego oraz wpływających na stopień ich nasilenia należą następujące zmienne (rysunek 1):

- typ odbiorcy - parametry demograficzne, geograficzne (rozumiane w znaczeniu dosłownym oraz w sensie miejsca zajmowanego przez daną osobę w stosunku do organizacji) określające jego indywidualny profil, liczba odbiorców, podobieństwa i różnice w porównaniu z odbiorcami zatrudnionymi w innych firmach (zwłaszcza konkurencyjnych wobec danej organizacji), rodzaj podpisanej umowy z pracodawcą i miejsce oraz forma jej realizowania;

- długość trwania więzi z odbiorca - długość okresu od momentu podpisania umowy o pracę oraz faza w cyklu życia danego pracownika;

- rola odbiorcy -jego wkład w realizację zadań firmy i ich charakter, zakres odpowiedzialności wynikający z miejsca zajmowanego $\mathrm{w}$ strukturze organizacyjnej przedsiębiorstwa, potencjał intelektualny, którym dysponuje odbiorca i stopień, w jakim może się on przyczynić do rynkowego sukcesu przedsiębiorstwa w przyszłości;

- pomoc niezbędna odbiorcy - rodzaj i wielkość zasobów informacyjnych, rzeczowych i finansowych, jakie są konieczne w celu optymalnego wykorzystania zdolności kreatywnych pracownika, sposób organizacji jego stanowiska pracy;

- satysfakcja odbiorcy-lojalność i zaangażowanie nabywcy, występowanie ewentualnych oporów przed wprowadzaniem zmian, konflikty i ich siła powstajace w układzie pionowym i poziomym, wartość wskaźnika fluktuacji.

Trzeba dodać, że część wymienionych czynników odnosi się wyłącznie do odbiorców wewnętrznych lub zewnętrznych, natomiast niektóre dotyczą obu grup nabywców.

\section{Satysfakcja zawodowa jako nadrzędne dążenie członków organizacji}

ożna jednak stwierdzić, że podstawową potrzeba, do której zaspokojenia zmierzają wszyscy adresaci działań z zakresu marketingu kadro- 
wego, niezależnie od tego, do jakiej grupy, czy kategorii należą, jest potrzeba satysfakcji z przynależności do danej organizacji oraz współtworzenia jej długookresowego sukcesu.

Odczuwanie satysfakcji zawodowej warunkują następujące czynniki ${ }^{1}$.

- Wiara w realność wytyczonego celu. Nie może on być jednak określony na zbyt niskim poziomie, ponieważ dążenie do jego osiągnięcia nie inspiruje wówczas do wykorzystania w pełni twórczych sił tkwiących w człowieku. Wyznaczanie celów ambitnych oraz ich realizowanie sprawia, że człowiek wierzy we własne siły i jest gotowy do podjęcia nowych ambitniejszych wyzwań, których spełnienie wymaga od niego pogłębiania wiedzy, zdobywania nowych umiejętności itp. Osiąga zatem dodatkowe korzyści.

- Autozaufanie, czyli głęboka wiara we własne możliwości. Człowiek odczuwający własną siłę oraz potrafiący właściwie ocenić jej rozmiary jest w stanie zrealizować do końca stojące przed nim zadania. Nie cofa się w połowie drogi, nie rezygnuje w chwili pojawienia się pierwszych trudności, ale poszukuje najlepszych rozwiązań pozwalających kontynuować rozpoczęte przedsięwzięcie. Co więcej, wystapienie ewentualnych utrudnień jeszcze silniej stymuluje go do działania, gdyż tym bardziej pragnie udowodnić samemu sobie i innym, że potrafi pokonać napotykane bariery. Im częściej próbuje znaleźć wyjście z trudnej sytuacji, tym większa cechuje go pomysłowość oraz intuicja, pogłębiają się jego zdolności obserwacji i wyciągania właściwych wniosków oraz analityczne, co łacznie wzbogaca jego kreatywne zdolności.

- Znajomość różnych sposobów osiagania celu, będąca bezpośrednim następstwem wcześniej wymienionych czynników, dzięki czemu człowiek zwiększa swoją wartość zarówno z własnego punktu widzenia, jak również z punktu widzenia organizacji, której jest członkiem.

Trzeba podkreślić, że dążenie do zaspokojenia różnych potrzeb przejawia się określonymi zachowaniami pracow-

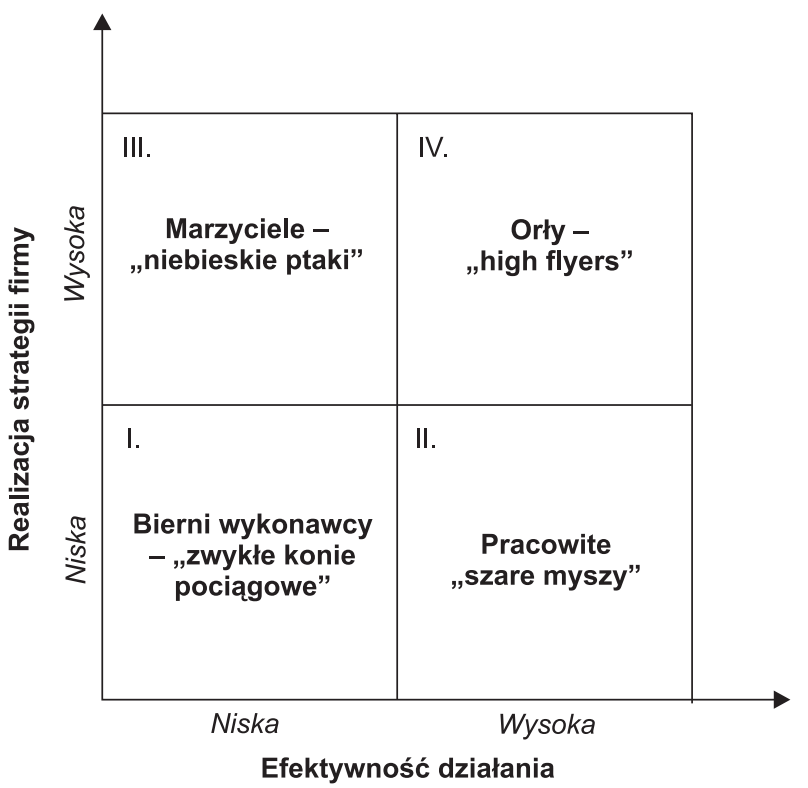

Rys. 2. Klasyfikacja kadry przedsiębiorstwa z punktu widzenia potencjału strategicznego i bieżącej efektywności działania

Źródło: Zarzadzanie strategiczne kapitatem ludzkim, praca zbiorowa pod redakcja A. LUDWICZYŃSKIEGO i K. STOBIŃSKIEJ, Poltext, Warszawa 2001, s. 97. ników, które związane sa ze zróżnicowaniem intelektualnych i fizycznych możliwości poszczególnych ludzi. Posiadanie różnego potencjału sprawia, że dla każdego człowieka co innego może wywoływać uczucie satysfakcji z życia zawodowego i osobistego. Jest to również związane ze stopniem zaangażowania członka organizacji w osiaganie jej celów. Zakres indywidualnych możliwości pracownika i jego wkład w działalność firmy jest podstawą dokonania podziału pracowników na cztery podstawowe grupy, których przedstawiciele odczuwają inne potrzeby oraz odmiennie się zachowują, aby je zrealizować (rysunek 2).

Najcenniejszą dla przedsiębiorstwa grupą są orły. Pracowników tych cechuje bowiem wysoka efektywność pracy w wysokim stopniu przyczyniająca się do realizacji strategicznych założeń całej organizacji. Trzeba jednak pamiętać, że zgodnie z zasadami marketingu personalnego każdy pracownik stanowi wartość samą w sobie, która współtworzy wartość całej organizacji. Natomiast, czy w praktyce wartość ta zostanie odkryta i pogłębiona, zależy od podjęcia przez pracodawcę właściwych działań zmierzajacych do stworzenia warunków sprzyjajacych indywidualnemu rozwojowi i satysfakcji każdego pracownika. Dlatego nie można bagatelizować znaczenia pozostałych grup przedstawionych na rysunku 2 (dotyczy to również tzw. biernych wykonawców) ${ }^{22}$.

\section{Podstawowe zasady funkcjonowania człowieka w organizacji}

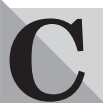

hociaż ludzie należa do różnych grup, stanowiac jednocześnie odrębne byty, ich dążenia podlegają pewnym schematom, które można ująć w następujących regułach ${ }^{3)}$.

- Aktywność człowieka jest celowa. Regulują ją świadome cele, co wynika z potrzeby samodoskonalenia się każdego człowieka. Zdaniem H. Seyle’a „, charakterystyczną cechą człowieka nie jest jego mądrość, lecz jego niestrudzona chęć pracy nad udoskonaleniem swojego środowiska i samego siebie".

- Naturalną potrzebą człowieka według A. Maslowa jest wykonywanie pełnej znaczenia pracy, odpowiedzialność, twórczość, spełnianie czynów wartościowych, bycie szlachetnym i sprawiedliwym. Ważne są nie tylko dobra materialne (np. pieniądze), ale również takie produkty niematerialne, jak przynależność, godność, szacunek, uznanie, praworządność, sprawiedliwa ocena. Tym bardziej że zgodnie z klasycznym aksjomatem, „odpowiedzialność idzie za wiedza"

- Człowiek w organizacji działa racjonalnie, oceniając każdą sytuację z punktu widzenia własnych interesów, reaguje na bodźce zewnętrzne nakierowane na niego w procesie motywowania, dokonując wyboru tych wartości, które sa dla niego cenniejsze. Jest to jednak możliwe, jeżeli posiada wystarczający stopień swobody działania i samodzielności odzwierciedlający tzw. zdolność do działania.

- Potrzeby człowieka sa zhierarchizowane, wyznaczaja cele, które chce zrealizować i pobudzaja go do aktywności zawodowej oraz osobistej.

- Człowiek jest członkiem konkretnej organizacji i jako taki przynależy do funkcjonujących $\mathrm{w}$ niej grup nieformalnych, z którymi czuje się ściśle związany, poszukując wsparcia i akceptacji w sposób świadomy lub podświadomy.

- Człowiek poprzez prace i w pracy doskonali swoje umiejętności, zdobywa wiedzę i doświadczenie, analizu- 
jąc relacje przyczynowo-skutkowe między własnym lub cudzym działaniem oraz jego wynikami. Kształtuje więc samego siebie, podnosząc jakość własnej pracy z korzyścią dla własnej osoby i dla całej organizacji.

- Człowiek realizuje cele organizacji, jeśli uzna je za własne, dostrzegając dodatnią zależność między realizacją celów firmy i swoich.

\section{Różnorodność i wielowymiarowość potrzeb zawodowych i osobistych}

$\mathbf{R}$

ozważając zagadnienia związane z potrzebami pracowników, należy pamiętać o konieczności rozróżniania dwóch ich grup. Pierwszą grupę stanowią potrzeby wynikające $\mathrm{z}$ realizowania zadań wiążących się z zajmowaniem określonego stanowiska pracy, które mogą lub wręcz muszą być zaspokajane przez kierownictwo przedsiębiorstwa oraz przez pracowników innych komórek organizacyjnych, np. przekazanie wyników analiz ekonomicznych przez pracowników działu ekonomicznego pracownikom działu marketingu.

Drugą grupę tworzą potrzeby odnoszące się do osobistych aspiracji danego członka organizacji, których spełnienie wymaga stworzenia przez kierownictwo firmy odpowiednich warunków o charakterze materialnym oraz niematerialnym. Ich realizacja jest środkiem do zaspokojenia przez daną osobę potrzeby nadrzędnej, jaką jest dążenie do samorealizacji zawodowej i osobistej. Jakkolwiek obie grupy potrzeb są istotne, a zaspokojenie pierwszej z nich warunkuje możliwość zaspokojenia drugiej grupy, w koncepcji marketingu personalnego nacisk kładzie się na potrzeby należące do drugiej kategorii.

Potrzeby odczuwane przez adresatów działań z zakresu marketingu personalnego można dzielić także ze względu na inne kryteria. Uwzględniając stopień powiązań z konkretną organizacją, można zatem wskazać potrzeby nabywców wewnętrznych i zewnętrznych. W przypadku odbiorców zewnętrznych jedną z kluczowych potrzeb jest rozpoczęcie satysfakcjonującej pracy w wybranej firmie. Natomiast potrzeby osób tworzących wewnętrzne środowisko przedsiębiorstwa wynikaja m.in. z zajmowanego przez nie miejsca w hierarchii organizacji. Ogólnie można je podzielić na cztery grupy potrzeb: potrzeby pracowników liniowych, potrzeby specjalistów, potrzeby kadry kierowniczej oraz potrzeby pracowników zatrudnionych w niepełnym wymiarze godzin ${ }^{5}$. Inne potrzeby mają tzw. nowi pracownicy (np. telepracownicy), inne zaś osoby wypełniające swoje obowiązki zawodowe w siedzibie firmy, z kolei wśród nich potrzeby determinowane są obszarem funkcjonalnym, z którym związana jest ich aktywność pracownicza ${ }^{6)}$.

Potrzeby pracowników wykazują pewne zróżnicowanie także w zależności od kraju pochodzenia danej osoby oraz kraju, w którym jest ona zatrudniona ${ }^{7}$. W przypadku państw europejskich nadrzędnym oczekiwaniem jest odpowiednie wynagrodzenie (79\% wskazań), podczas gdy w USA zajmuje ono dalszą pozycję w hierarchii potrzeb pracowników amerykańskich ${ }^{8}$. Znacznie większe znaczenie przywiązują oni do zaspokojenia potrzeb o charakterze niematerialnym. Wyniki badań ankietowych przeprowadzonych przez The Conference Board wskazują, że pracownicy amerykańscy oczekują od pracodawców przede wszystkim: interesującej pracy, otwartej i dwukierunkowej komunikacji, możliwości rozwoju, realistycznie formułowanych przez zarządzających wymagań, bezpieczeństwa zatrudnienia, równowagi między pracą a życiem prywatnym, partycypacji w procesach decyzyjnych
Niezależnie od tego, czy bierze się pod uwagę potrzeby odczuwane przez pracowników potencjalnych, czy też potrzeby aktualnych członków organizacji, dążenia każdego z nich są wypadkową (podobnie jak w klasycznej koncepcji marketingu) ich cech wyodrębnionych ze względu na różnorodne kryteria (demograficzne, geograficzne, behawioralne, psychograficzne itp. ${ }^{9)}$. Szczególnie duże znaczenie w przypadku marketingu personalnego ma płeć ${ }^{10)}$ i wiek odbiorcy oraz jego miejsce zamieszkania, gdyż czynniki te w decydującym stopniu wpływają na kształtowanie sposobu postrzegania możliwości realizacji aspiracji zawodowych przez każdego człowieka.

dr Agnieszka Izabela Baruk Zakład Marketingu Produktów Żywnościowych Katedra Ekonomiki i Organizacji Agrobiznesu Akademia Rolnicza w Lublinie

\section{PRZYPISY}

1) Podobne czynniki wskazywane sa jako warunki osiagnięcia celu. Zdaniem autorki determinują one także odczuwanie satysfakcji z pracy, która jest przecież celem praktycznie każdego członka organizacji. Por. Zarzadzanie wartościa fir$m y$, praca zbiorowa pod red. A. HERMANA, A. SZABLEWSKIEGO, Poltext, Warszawa 1999, s. 97.

2) Można w tym miejscu postawić tezę, że wkład pracownika w rozwój firmy w większym stopniu zależy od umiejętności pracodawcy wzbudzenia jego ukrytych zdolności oraz ich pielęgnowania niż od samych członków organizacji. Niewielu jest bowiem ludzi, którzy są na tyle wewnętrznie zdyscyplinowani, że potrafia sie nieustannie automotywować i indywidualnie weryfikować swoje działania. Nawet samorealizacja nie będzie pełna bez udziału innych osób, a zwłaszcza bez ich życzliwości i wsparcia psychicznego.

3) Por. J. PENC, Kreatywne kierowanie. Organizacja i kierownik jutra. Rozwiazywanie problemów kadrowych, Agencja Wydawnicza Placet, Warszawa 2000, s. 31-47.

4) P.F. DRUCKER, Zarzadzanie w czasach burzliwych, Czytelnik, Warszawa 1995, s. 191.

5) Oczywiście podział ten odnosi się do potrzeb o charakterze zawodowym, aczkolwiek niejednokrotnie pracownicy zajmujący stanowiska na różnych szczeblach hierarchicznych mają w praktyce także odmienne aspiracje osobiste. Por. A.S. TSUI, G.T. MILKOVICH, Personnel Department Activities: Constituency Perspectives and Preferences, „Personnel Psychology" 1987, nr 40, s. 519-537.

6) Należy pamiętać, że coraz częściej organizacje funkcjonować będą w ramach struktur procesowych, odchodząc tym samym od struktury funkcjonalnej, co spowoduje zmniejszenie lub całkowite wyeliminowanie znaczenia obszaru funkcjonalnego. Na razie jednak w Polsce dominują przedsiębiorstwa zorganizowane zgodnie z założeniami klasycznych typów struktur, wśród których najczęściej spotykanąjest struktura funkcjonalna, dlatego nie można pomijać tego czynnika.

7) Nie są to pojęcia równoznaczne, ponieważ należy uwzględnić fakt, że część osób pracuje w innym kraju niż kraj pochodzenia, co może być spowodowane migracją lub oddelegowaniem danej osoby do pracy w oddziale, czy filii przedsiębiorstwa zlokalizowanych w innym państwie (w przypadku przedsiębiorstw o zasięgu międzynarodowym lub globalnym). 8) J. BRILMAN, Nowoczesne koncepcje $i$ metody zarzadzania, PWE, Warszawa 2002, s. 352.

9) Por. A. BARUK, Potrzeby nabywców i ich zachowania rynkowe jako podstawa dziatalności przedsiębiorstwa, [w:] Future 2002. Zarzadzanie przyszłościa przedsiębiorstwa, materiały $\mathrm{z}$ konferencji naukowej pod red. E. SKRZYPEK, Wydawnictwo Uniwersytetu Marii Curie-Skłodowskiej, Lublin 2002, t. 2, s. 69-83

10) Por. A. BARUK, Równość szans rozwoju zawodowego kobiet i mężczyzn - teoria czy praktyka?, [w:] Nowe tendencje $w z a-$ rzadzaniu wartościa przedsiębiorstwa. Aktualny stan i perspektywy rozwoju, pod red. E. URBAŃCZYKA, Wydawnictwo Kreos, Szczecin 2003, t. I, s. 289-300. 